\title{
Hydrological Response of Watershed Systems to Land Use/Cover Change. A Case of Wami River Basin
}

\author{
Joel Nobert ${ }^{*}$ and Jiben Jeremiah
}

Water Resources Engineering Department, University of Dar es Salaam, Box 35131, Dar es Salaam, Tanzania

\begin{abstract}
Wami river basin experiences a lot of human disturbances due to agricultural expansion, and increasing urban demand for charcoal, fuel wood and timber; resulting in forest and land degradation. Comparatively little is known about factors that affect runoff behaviour and their relation to landuse in data poor catchments like Wami. This study was conducted to assess the hydrological response of land use/cover change on Wami River flows. In data poor catchments, a promising way to include landuse change is by integrating Remote Sensing and semi-distributed rainfall-runoff models. Therefore in this study SWAT model was selected because it applies semi-distributed model domain. Spatial data (landuse, soil and DEM-90m) and Climatic data used were obtained from Water Resources Engineering Department, government offices and from the global data set. SWAT model was used to simulate streamflow for landuse/landcover for the year 1987 and 2000 to determine the impact of land use/cover change on Wami streamflow after calibrating and validating with the observed flows. Land use maps of 1987 and 2000 were derived from satellite images using ERDAS Imagine 9.1 software and verified by using 1995 land use which was obtained from Institute of Resource Assessment (IRA).

Findings show that there is decrease of Forest area by 1.4\%, a 3.2\% increase in Agricultural area, 2.2\% increase in Urban and $0.48 \%$ decreases in Waterbody area between 1987 and 2000. The results from SWAT model simulation showed that the average river flows has decreased from $166.3 \mathrm{~mm}$ in 1987 to $165.3 \mathrm{~mm}$ in 2000 . The surface runoff has increased from $59.4 \mathrm{~mm}(35.7 \%)$ in 1987 to $65.9 \mathrm{~mm}(39.9 \%)$ in 2000 and the base flow decreased from $106.8 \mathrm{~mm}(64.3 \%)$ to $99.4 \mathrm{~mm}$ $(60.1 \%)$ in 1987 and 2000 respectively. This entails that the increase of surface runoff and decrease of base flows are associated with the land use change.
\end{abstract}

Keywords: Landuse/Landcover change, Hydrological response, Data poor catchments.

\section{INTRODUCTION}

During recent decades, concerns about the impacts of changing patterns of landuse associated with deforestation and agricultural transformation on water resources have created social and political tensions from local to national levels. This shift towards an increasingly urbanized landscape has generated a number of changes in ecosystem structure and function, resulting in an overall degradation of the ecological services provided by the natural system in Wami river basin. Ecosystem services are defined as the multiple benefits available to humans, animals and plants that are derived from environmental processes and natural resources ([1] Costanza et al. 1997). Ecosystem services provided by surface water systems are vital to the health and success of human development. For example, many urban areas depend heavily on streams to provide water for municipal, agricultural and commercial uses ([2] Meyer et al. 2005).

Threats to the Ukaguru Mountain forest in Wami river basin include encroachment from farmers and the plantation forest, fuel-wood collection and fires spreading from lowland areas. There is a high level of destruction of the forests in the Nguru Mountains, which have more than 40 endemic

*Address correspondence to this author at the University of Dar es Salaam, Water Resources Engineering Department, Tanzania; Tel: +255-222410029; Fax: +255-222410029; E-mail: nobert@udsm.ac.tz species. The threats to the Nguru forests are agricultural encroachment and under planting of forest with cardamom and banana, pit sawing of timber and fires. Other disturbances include timber harvesting; livestock grazing; pole cutting; firewood collection and charcoal production ([3] Doggart and Loserian 2007). Doggart and Loserian (2007) state that the level of disturbance caused by cardamom cultivation, hunting and timber harvesting has reached critical levels and urgent action is needed.

Identifying and quantifying the hydrological consequences of land-use change are not trivial exercises, and are complicated by: (1) the relatively short lengths of hydrological records; (2) the relatively high natural variability of most hydrological systems; (3) the difficulties in 'controlling' land-use changes in real catchments within which changes are occurring; (4) the relatively small number of controlled small-scale experimental studies that have been performed; and (5) the challenges involved in extrapolating or generalizing results from such studies to other systems. Much of our present understanding of land-use effects on hydrology is derived from controlled, experimental manipulations of the land surface, coupled with pre- and post-manipulation observations of hydrological processes, commonly precipitation inputs and stream discharge outputs.

In order to account for the natural heterogeneity within watersheds as well as anthropogenic activities, hydrologic simulation models are often employed as watershed man- 


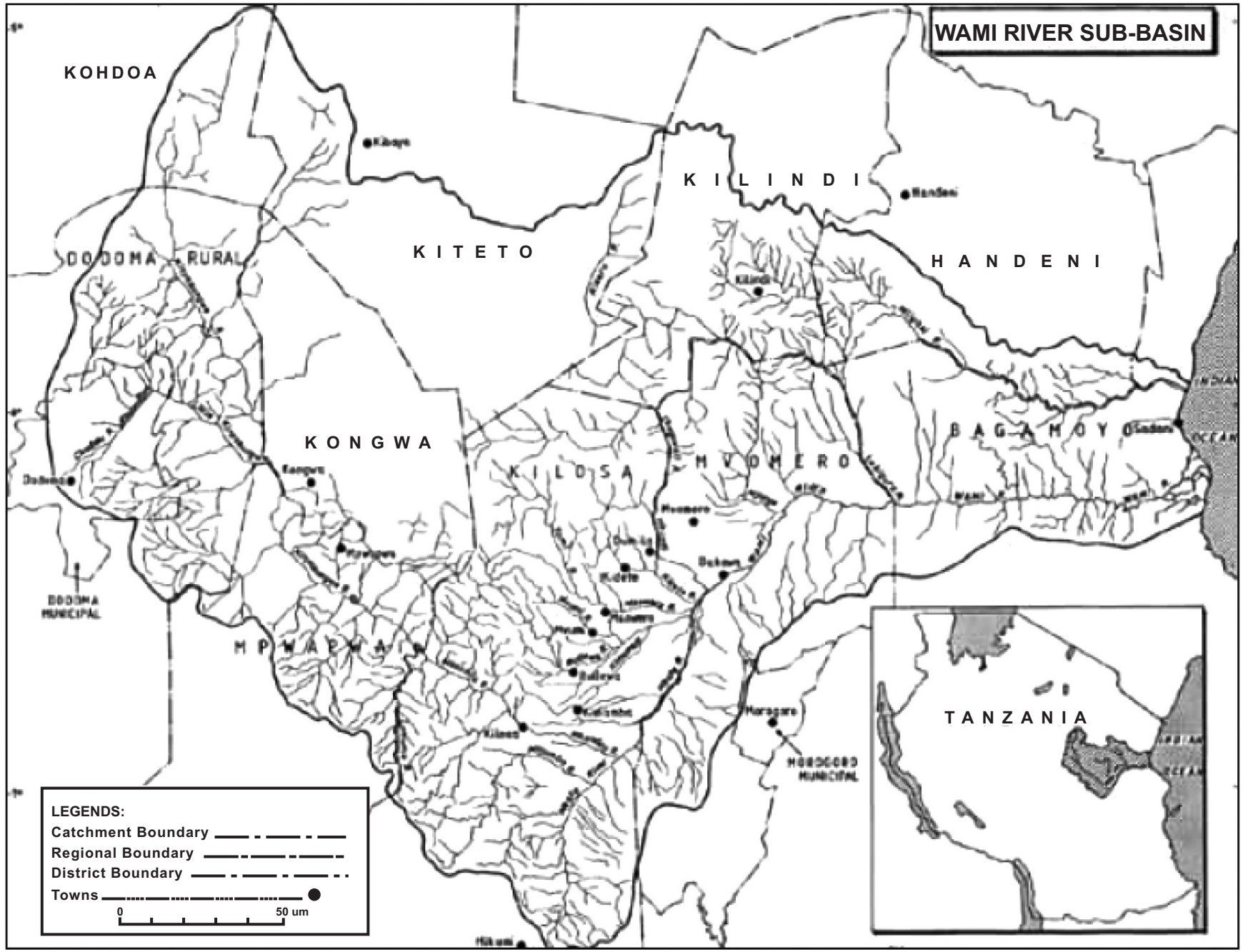

Fig. (1). Wami Sub-basin ([10] WRBWO 2007a).

agement tools. Simulation models have proven useful for planning managers as a form of decision support for evaluating urbanized watersheds. While conservation efforts have often focused on maximizing the quantity of land conserved, research efforts in landscape ecology have shown that the spatial pattern of land conversion can have a significant effect on the function of ecological processes, particularly when examining watershed networks. Recently, many research efforts have been launched to predict the hydrologic response of varying scenarios of land use modification through the development and application of multiple models ([4] Im et al. 2009). Current models vary tremendously in their degree of complexity and can range from statistical simulations, such as a regression analysis or the Spatially Referenced Regressions on Watershed Attributes (SPARROW) ([5] Schwarz et al. 2006) model, to more processbased models, such as the Soil and Water Assessment Tool (SWAT) ([6] Neitsch et al. 2005a) or the Hydrologic Simulation Program Fortran (HSPF) ([7] U.S. EPA 1997). In data poor basins, a promising way to include landuse change is by integrating Remote Sensing and semi-distributed rainfallrunoff models. Therefore in this study SWAT model was selected because it applies semi-distributed model domain.

\section{DESCRIPTION OF THE STUDY AREA}

From its source in the Eastern Arc Mountain ranges of Tanzania, the Wami River flows in a south-eastwardly direction from dense forests, across fertile agricultural plains and through grassland savannahs along its course to the Indian Ocean. Located between $5^{\circ}-7^{\circ} \mathrm{S}$ and $36^{\circ}-39^{\circ} \mathrm{E}$, the Wami River Sub-Basin extends from the semi-arid Dodoma region to the humid inland swamps in the Morogoro region to Saadani Village in the coastal Bagamoyo district. It encompasses an area of approximately $43,000 \mathrm{~km}^{2}$ and spans an altitudinal gradient of approximately 2260 meters (Fig. 1). According to a 2002 census, the sub-basin is home to 1.8 million people in 12 districts: Kondoa, Dodoma-urban, Bahi, Chamwino, Kongwa, Mpwapwa, (Dodoma Region) Kiteto, Simanjiro (Manyara Region), Mvomero, Kilosa (Morogoro Region), Handeni, Kilindi, (Tanga Region) and Bagamoyo (Coast Region). It also comprises one of the world's most important hotspots of biological diversity: the Eastern Arc Mountains and coastal forests ([8] WRBWO 2008a).

Average annual rainfall across the Wami sub-basin is estimated to be $550-750 \mathrm{~mm}$ in the highlands near Dodoma, 900-1000 $\mathrm{mm}$ in the middle areas near Dakawa and 900$1000 \mathrm{~mm}$ at the river's estuary. Most areas of the Wami sub- 


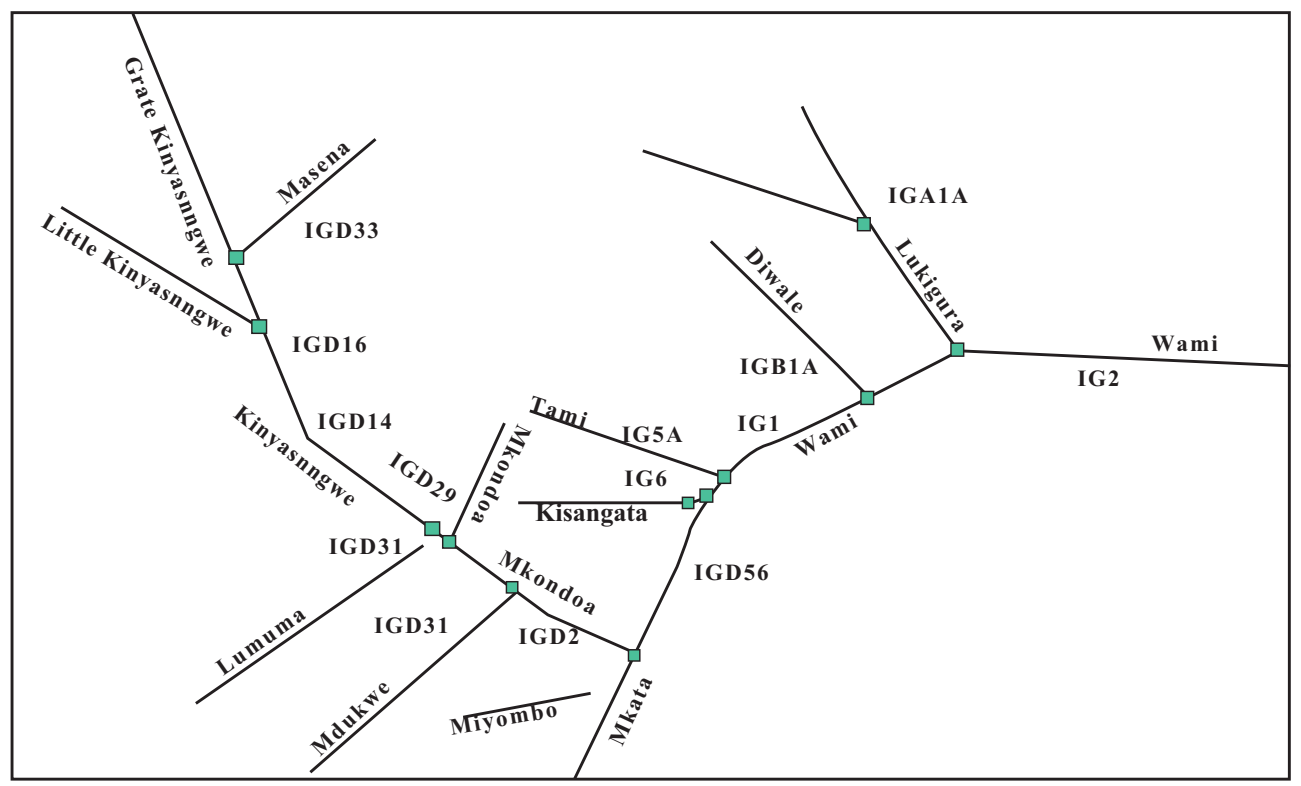

Fig. (2). Schematic representation of the river network ([11] WRBWO 2007d).

basin experience marked differences in rainfall between wet and dry seasons. Although there is some inter-annual variation in timing of rainfall, dry periods typically occur from July to October and wet periods from November to December (vuli rains) and from March to June (masika rains) ([9] WRBWO 2007b). The river network in the Wami sub-basin drains mainly the arid tract of Dodoma, the central mountains of Rubeho and Nguu and the northern Nguru Mountains. The Wami subbasin river network (WRBWO 2008a) comprises the main Wami River and its five major tributaries-Lukigura, Diwale, Tami, Mvumi/Kisangata and Mkata (Fig. 2). The Mkata tributary is the largest and includes two major sub tributaries, the Miyombo and the large Mkondoa. The Mkondoa River includes the major Kinyasungwe tributary with the Great and Little Kinyasungwe draining the dry upper catchments in Dodoma.

\section{METHODOLOGY}

\subsection{SWAT Model}

The Soil and Water Assessment Tool (SWAT) is a basinscale model that operates on a daily time step to predict the impact of land use and management practices on water quality within complex catchments ([12] Arnold and Fohrer 2005). Originally developed by Dr. Jeff Arnold for the USDA Agricultural Research Service, SWAT was chosen for this study for its focus on modeling the hydrological impacts of land use change, while specifically accounting for the interactions between regional soil, land use and slope characteristics ([13] Arnold et al. 1998).

SWAT is a continuous, long-term, distributed parameter model designed to predict the impact of land management practices on the hydrology and sediment and contaminant transport in agricultural watersheds (Arnold et al., 1998). SWAT subdivides a watershed into subbasins connected by a stream network, and further delineates HRUs (Hydrologic Response Units) consisting of unique combinations of land cover and soils within each subbasin. The model assumes that there are no interactions among HRUs, and these HRUs are virtually located within each subbasin. HRUs delineation minimizes the computational costs of simulations by lumping similar soil and landuse areas into a single unit ([14] Neitsch et al, 2002).

SWAT is able to simulate surface and subsurface flow, sediment generation and deposition, and nutrient fate and movement through landscape and river. The present study focuses only on the hydrological component of the model. The hydrologic routines within SWAT account for snow accumulation and melt, vadose zone processes (i.e., infiltration, evaporation, plant uptake, lateral flows, and percolation), and groundwater flows. Surface runoff is estimated using a modified version of the USDA-SCS curve number method ([15] USDA-SCS, 1972). A kinematic storage model is used to predict lateral flow, whereas return flow is simulated by creating a shallow aquifer (Arnold et al., 1998). The SWAT model has been extensively tested for hydrologic modelling at different spatial scales.

The data required to run SWAT were collected and included elevation, land use, soil, climatic data and stream flow information, as detailed in the following section. After model set-up was completed, the simulation was run and calibration procedures were used to improve model accuracy. Next, a future land used scenario was created based on previous land use change for the area and the output from the future scenario was compared to the current baseline results, in order to assess the variance in streamflow.

\subsection{Data Preparation}

Data is the crucial input for the model in hydrological modelling. Data preparation, analysis and formatting to suit the required model input is important and has influences on the model output. The relevant time series data used for this study included daily rainfall data, stream flows, temperature (minimum and maximum), relative humidity, wind speed and solar radiation. Data were collected from the University of Dar es Salaam (UDSM), Water Resources Engineering Department (WRED) data base, Ministry of Water at Ubungo, Wami Ruvu Basin office at Morogoro and Tanzania Meteorological Authority office (TMA). These data records 
Table 1. Available Rainfall Data

\begin{tabular}{|c|c|c|c|c|c|c|}
\hline $\mathbf{S} / \mathbf{N}$ & NAME & Start Year & End Year & Length of Years & Elevation (a.m.s.l) & \%Missing \\
\hline 1 & 9635001 & $1 / 1 / 1932$ & $31 / 12 / 1995$ & 64 & 1120 & 26.05 \\
\hline 2 & 9536004 & $1 / 1 / 1962$ & $31 / 12 / 1991$ & 30 & 1524 & 11.00 \\
\hline 3 & 9636029 & $1 / 1 / 1972$ & $31 / 12 / 1990$ & 19 & 914 & 8.02 \\
\hline 4 & 9635012 & $1 / 1 / 1961$ & $31 / 12 / 1990$ & 30 & 1133 & 18.03 \\
\hline 5 & 9636008 & $1 / 1 / 1947$ & $31 / 12 / 1995$ & 49 & 1067 & 27.03 \\
\hline 6 & 9636018 & $1 / 1 / 1956$ & $31 / 12 / 1995$ & 40 & 1676 & 34.03 \\
\hline 7 & 9635014 & $1 / 1 / 1962$ & $31 / 12 / 1995$ & 34 & 1067 & 20.07 \\
\hline 8 & 9636013 & $1 / 1 / 1953$ & $31 / 12 / 1995$ & 43 & 914 & 41.10 \\
\hline 9 & 9736007 & $1 / 1 / 1960$ & $31 / 12 / 1989$ & 30 & 1783 & 10.17 \\
\hline 10 & 9636027 & $1 / 1 / 1970$ & $31 / 12 / 1993$ & 24 & 1880 & 12.53 \\
\hline 11 & 9636026 & $1 / 1 / 1970$ & $31 / 12 / 1989$ & 20 & 1786 & 15.57 \\
\hline 12 & 9536000 & $1 / 1 / 1925$ & $31 / 12 / 1961$ & 37 & 1037 & 21.97 \\
\hline 13 & 9537009 & $1 / 1 / 1976$ & $31 / 12 / 1994$ & 19 & 1150 & 52.12 \\
\hline
\end{tabular}

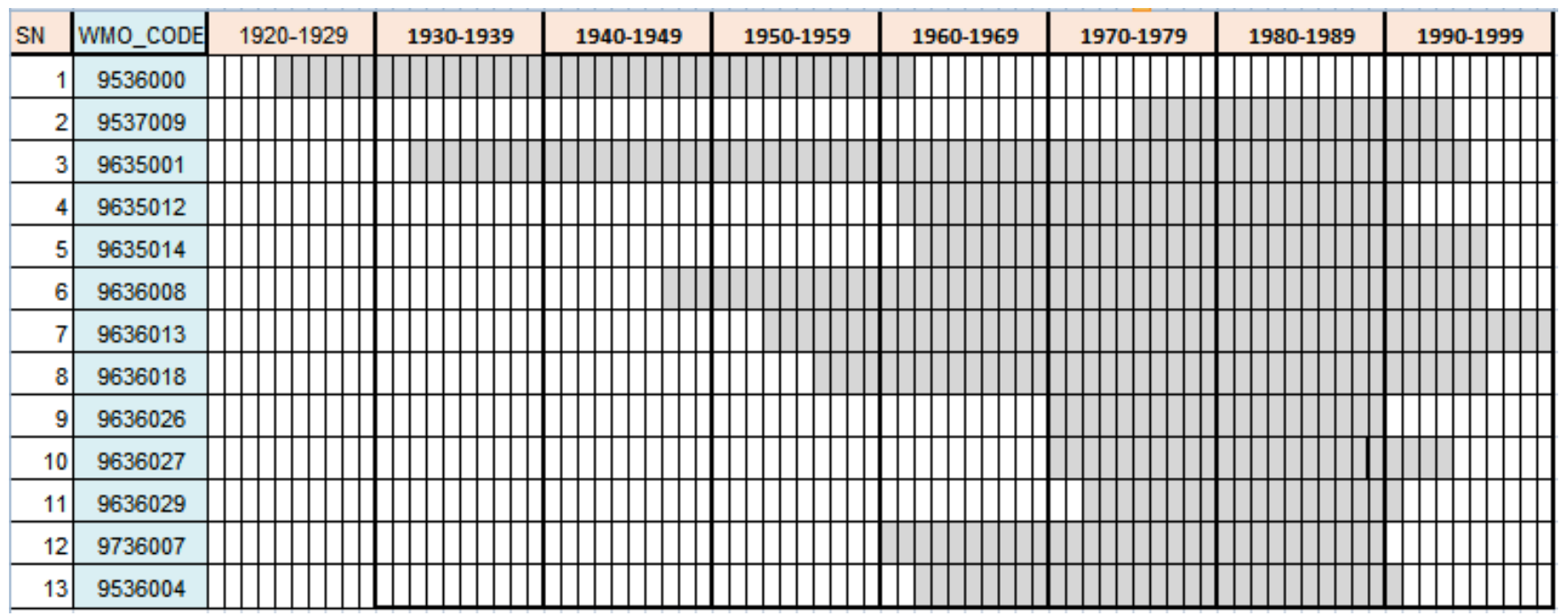

Fig. (3). Temporal distribution of available rainfall data.

Table 2. Climatic and Flow Data

\begin{tabular}{|c|c|c|c|c|}
\hline Station Code & Variables & Start Year & End Year & Number of Years \\
\hline \hline \multirow{3}{*}{9635001} & Relative humidity & 1974 & 1984 & 10 \\
\cline { 2 - 5 } & Wind speed & 1974 & 1984 & 10 \\
\cline { 2 - 5 } & Solar radiation & 1974 & 1984 & 10 \\
\cline { 2 - 5 } & Max and Min temperature & 1974 & 1984 & 10 \\
\hline $1 G 2$ & Flow & 1974 & 1984 & 10 \\
\hline
\end{tabular}

differ in length from the starting and ending dates (Table 1 \& Fig. 3). The selection of the time series data was performed on the basis of availability and quality of data.

Flow data at the outlet of subbasin (1G2) were used for calibration purpose. Table 2 shows the climatic data and flow data used for this study.

Spatial data used included land use data from $30 \mathrm{~m}$ Landsat TM Satellite, Digital Elevation Model (DEM) with 90-m resolution and Soil data from Soil and Terrain Database for Southern Africa (SOTERSAF).

\subsection{Model Set-Up}

\subsubsection{Watershed Delineation}

The watershed delineation interface in ArcView (AVSWAT) is separated into five sections including DEM Set Up, Stream Definition, Outlet and Inlet Definition, Wa- 


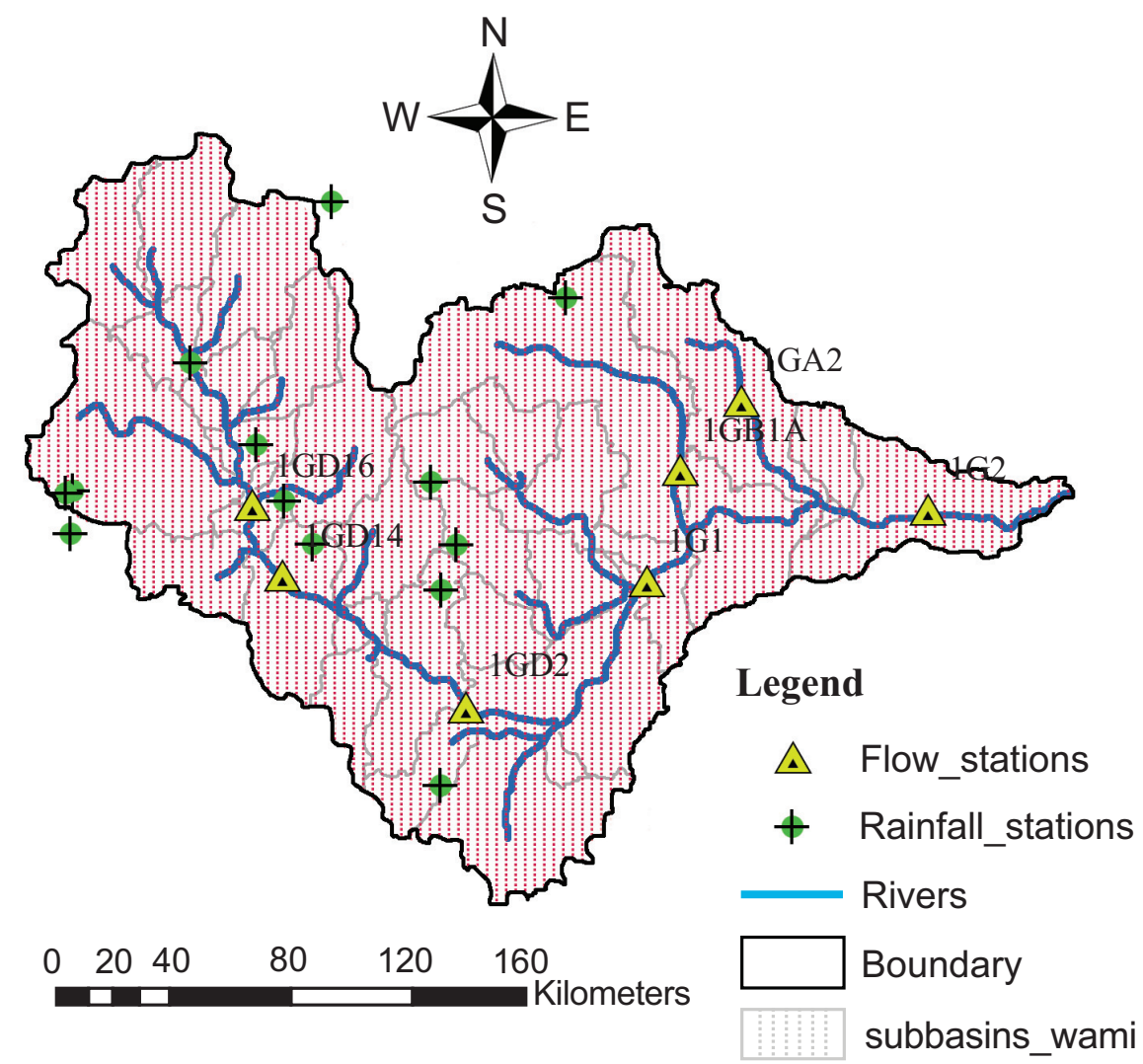

Fig. (4). Delineated Wami catchment.

tershed Outlet(s) Selection and Definition and Calculation of Subbasin parameters. In order to delineate the networks subbasins, a critical threshold value is required to define the minimum drainage area required to form the origin of a stream.

After the initial subbasin delineation, the generated stream network can be edited and refined by the inclusion of additional subbasin inlet or outlets. Adding an outlet at the location of established monitoring stations is useful for the comparison of flow concentrations between the predicted and observed data. Therefore, one subbasin outlet was manually edited into the watershed based on known stream gage location that had sufficient stream flow data available from 19741984. The delineated catchment is shown in Fig. (4).

\subsubsection{HRU Definition}

The SWAT (ArcView version) model requires the creation of Hydrologic Response Units (HRUs), which are the unique combinations of land use and soil type within each subbasin. The land use and soil classifications for the model are slightly different than those used in many readily available datasets and therefore the landuse and soil data were reclassified into SWAT land use and soil classes prior to running the simulation.

\subsection{Land Use Change Analysis}

Land use/cover classification was derived from Landsat satellite images of two different years 1987 and 2000. Supervised classification using ERDAS Imagine software was used and the final classification resulted into four land cover classes namely forest, agriculture, water bodies, and urban areas. The procedure used for the classification of the satellite images and the classified maps are shown in Figs. $(5 \&$ 6), respectively. These images were verified by using the existing landuse/ landcover map of 1995 which was prepared by Institute of Resource Assessment (IRA) through the ground truthing.

\subsection{Calibration/Sensitivity Analysis}

The time series of discharge at the outlet of the catchment (1G2) was used as data for calibration and validation for SWAT model, the model was calibrated using the measurements from 1974 to 1980 and first the sensitive parameters which govern the watershed were obtained and ranked according to their sensitivity (Table 3). The parameters were optimized first using the auto calibration tool, then calibration was done by adjusting parameters until the simulated and observed value showed good agreement.

\subsection{Model Efficiency Criteria}

\section{Nash-Sutcliffe Efficiency (NSE)}

The Nash-Sutcliffe efficiency (NSE) is a normalized statistic that determines the relative magnitude of the residual variance ("noise") compared to the measured data variance ("information") ([16] Nash and Sutcliffe, 1970). NSE indicates how well the plot of observed versus simulated data fits the $1: 1$ line. NSE is computed as shown below. 


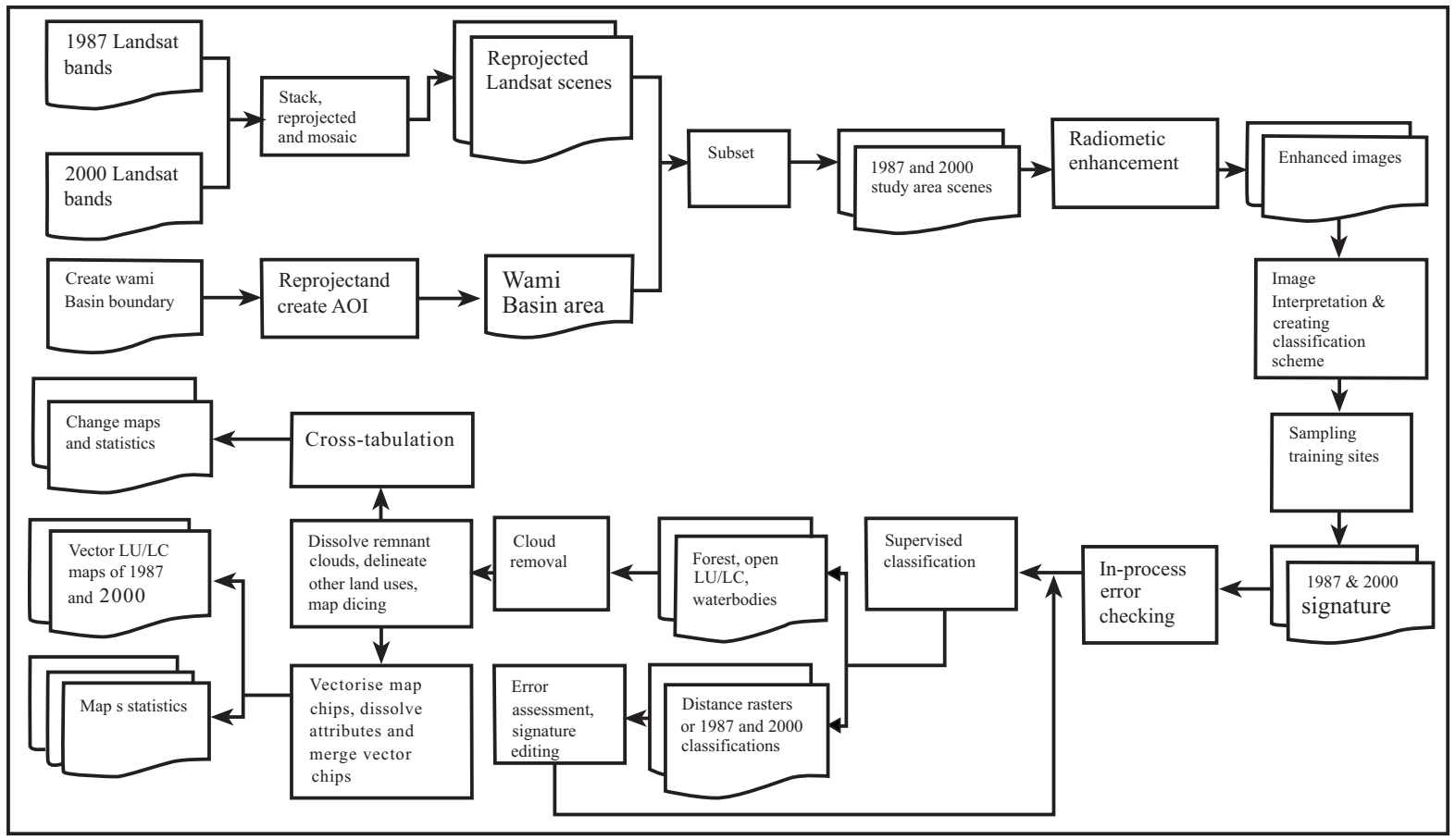

Fig. (5). Flowchart for the classification of the satellite images.

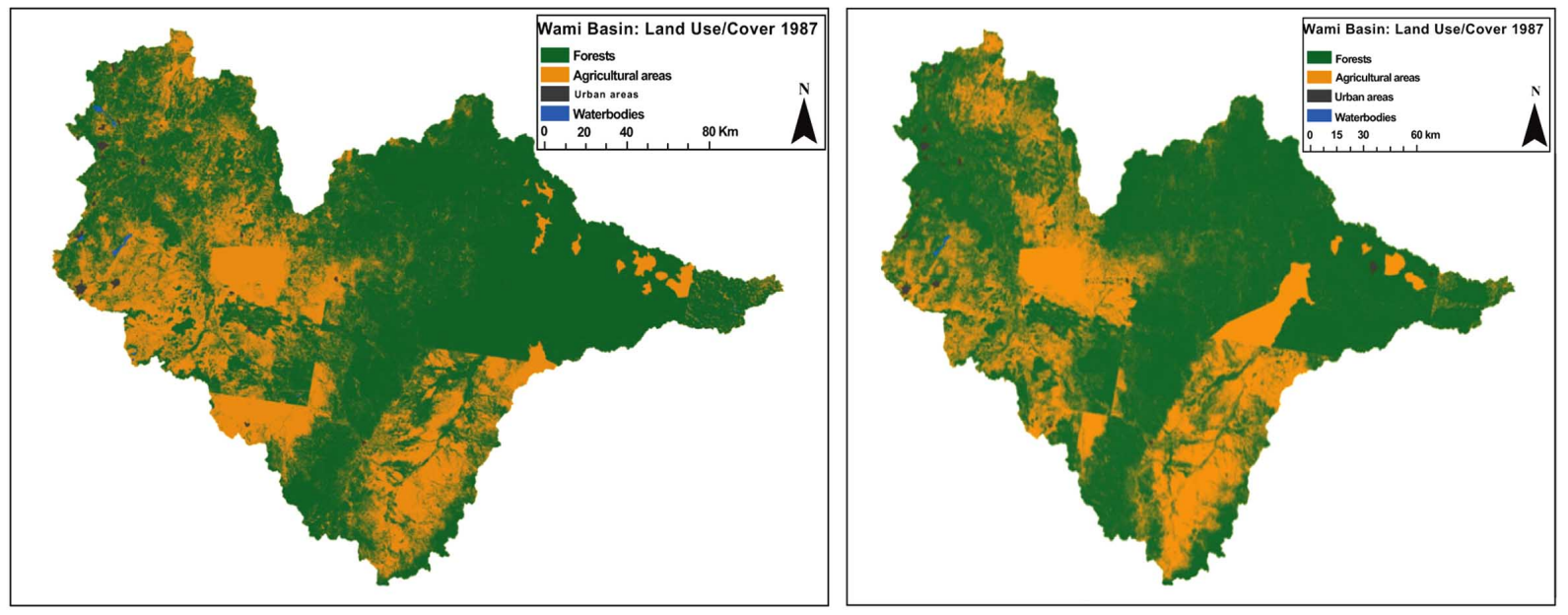

Fig. (6). Land use/land cover classifications for the year 1987 (left) and 2000 (right).

Table 3. Sensitivity Ranking of the Parameters

\begin{tabular}{|l|c|}
\hline \multicolumn{1}{|c|}{ Parameters } & Symbol \\
\hline \hline SCS runoff curve number & CN2 \\
\hline Surface runoff lag time(days) & SURLAG \\
\hline Soil Evaporation Compensation Factor & ESCO ALPHA_BF \\
\hline Base flow Alpha Factor (days) & SOL_Z \\
\hline Soil Depth(m) & SOL_AWC \\
\hline Available water capacity & Sol_K \\
\hline Saturated hydraulic conductivity & CH_K2 \\
\hline Effective hydraulic conductivity in main channel alluvium & 5 \\
\hline Maximum canopy index & Canmx \\
\hline Threshold water depth in the shallow aquifer for flow & 7 \\
\hline Ground Water revap coefficient & GWQMN \\
\hline
\end{tabular}


Table 4. Land Use Change Summary

\begin{tabular}{|c|c|c|c|c|c|c|}
\hline \multirow[t]{2}{*}{ Land cover } & \multicolumn{3}{|c|}{ Land Cover Area $\left(\mathrm{km}^{2}\right)$} & \multicolumn{2}{|c|}{ Area Change $\left(\mathrm{km}^{2}\right)$} & \multirow{2}{*}{$\begin{array}{c}\begin{array}{c}\text { Percentage Area } \\
\text { Change }(\%)\end{array} \\
1987 \_2000\end{array}$} \\
\hline & Year 1987 & Year 1995 & Year 2000 & 1987_1995 & 1987_2000 & \\
\hline Agricultural area & 16527.58 & 16815.33 & 16916.68 & 287.75 & 389.12 & 3.17 \\
\hline Forest area & 19092.57 & 18799.33 & 18655.62 & -293.25 & -459.77 & -1.36 \\
\hline Water Bodies & 1020.23 & 1019.01 & 994.91 & -1.22 & -2.53 & -0.48 \\
\hline Urban Area & 3359.62 & 3366.33 & 3432.79 & 6.72 & 73.18 & 2.23 \\
\hline Total & 40000 & 40000 & 40000 & 0 & 0 & \\
\hline
\end{tabular}

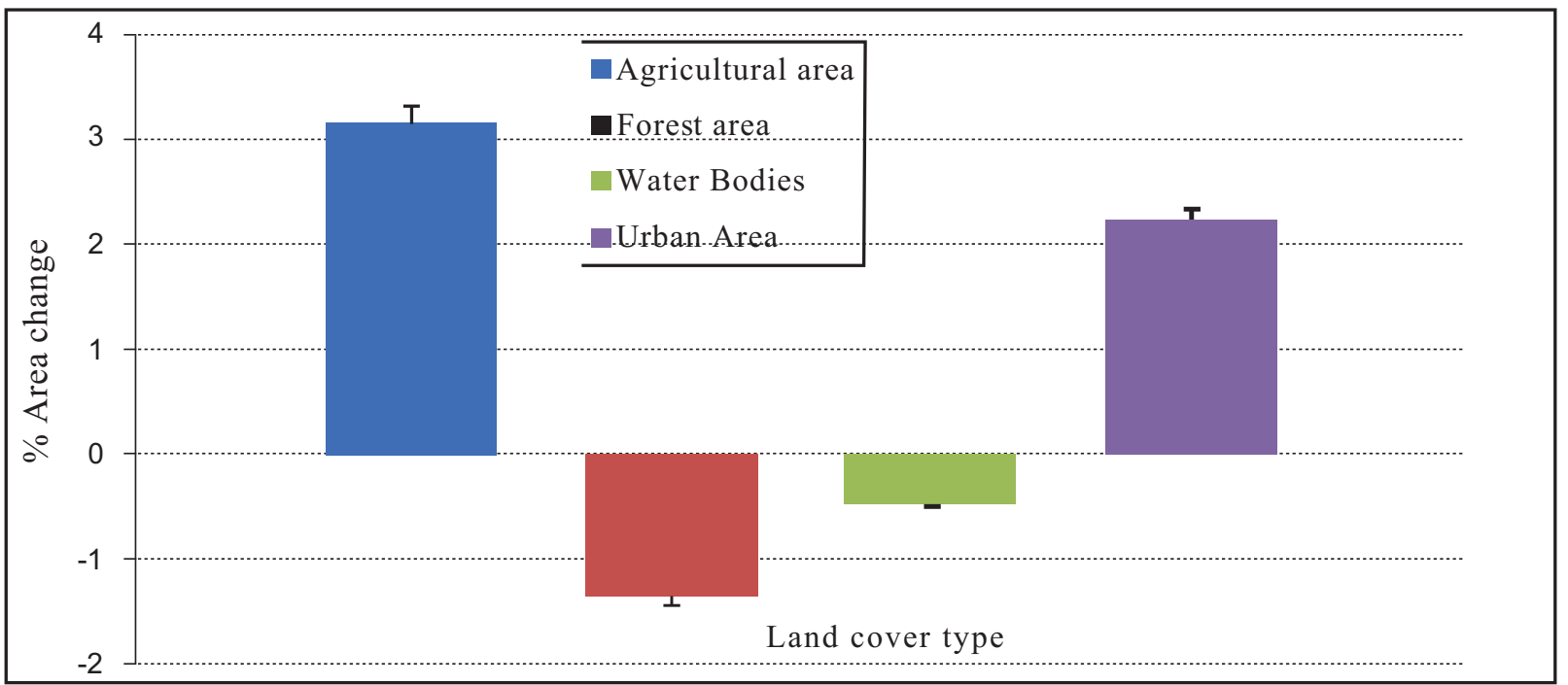

Fig. (7). Percentage of land use/cover change between 1987 and 2000.

$$
N S E=1-\left[\frac{\sum_{i=1}^{n}\left(Y_{i}^{\text {obs }}-Y_{i}^{\text {sim }}\right)^{2}}{\sum_{i=1}^{n}\left(Y_{i}^{\text {obs }}-Y^{\text {mean }}\right)^{2}}\right]
$$

Where $Y_{i}{ }^{o b s}$ is the $i$ - th observation for the constituent being evaluated, $Y_{i}{ }^{\text {sim }}$ is the $i$ - th simulated value for the constituent being evaluated, $Y^{\text {mean }}$ is the mean of observed data for the constituent being evaluated, and $n$ is the total number of observations.

NSE ranges between $-\infty$ and 1.0 ( 1 inclusive), with $\mathrm{NSE}=1$ being the optimal value. Values between 0.0 and 1.0 are generally viewed as acceptable levels of performance, whereas values $<0.0$ indicates that the mean observed value is a better predictor than the simulated value, which indicates unacceptable performance.

\section{Index of Volumetric Fit (IVF)}

Index of Volumetric Fit (IVF) is the ratio of the total estimated volume $\mathrm{Q}_{\mathrm{s}}$, to the total observed volume $\mathrm{Q}_{\mathrm{o}}$, and is expressed as.

$$
I V F=\frac{\sum_{i=1}^{N}\left(Q_{s}\right)_{i}}{\sum_{i=1}^{N}\left(Q_{o}\right)_{i}}
$$

Where
IVF is the Index of Volumetric Fit

$\left(\mathrm{Q}_{\mathrm{S}}\right)_{\mathrm{i}}$ is volume of the estimated flow

$\left(Q_{0}\right)$ is total volume of observed flow

\subsection{Analysis of Impact of Landuse/Cover Change on Streamflows}

Three scenarios were used for the analysis of impact of landuse/cover change on streamflows. In the first scenario the land use/cover for 1995 was used for calibration and validation of the model. In the second and third scenarios land use maps for the year 1987 and 2000, respectively, were used to simulate the impact of landuse change on streamflows. Hydrological characteristics that were studied and compared were surface runoff and ground water (base flow) components.

\section{RESULTS AND DISCUSSIONS}

\subsection{Landuse/Cover Change Analysis}

The results for landuse/cover change analysis (Table 4 \& Fig. 7) show that between 1987 and 2000 there was an increase of $3.17 \%$ in agricultural land, $1.36 \%$ decrease of forest, $0.48 \%$ decrease of water bodies, and $2.23 \%$ increase in urban areas. The area change between 1987 and 2000 shows a decrease of forest area and an increase in agricultural area. The decrease in forest area and increase of agriculture are interdependent in Wami basin. The activities which caused 
Table 5. Long Term Water Balance Simulation Results

\begin{tabular}{|c|c|c|c|}
\hline & Total Water Yield (mm) & Base Flow (mm) & Surface Flow (mm) \\
\hline \hline Actual & 169.5 & 107.2 & 62.2 \\
\hline SWAT & 165.4 & 102.7 & 62.6 \\
\hline
\end{tabular}

Observed

Simulatec

Rain

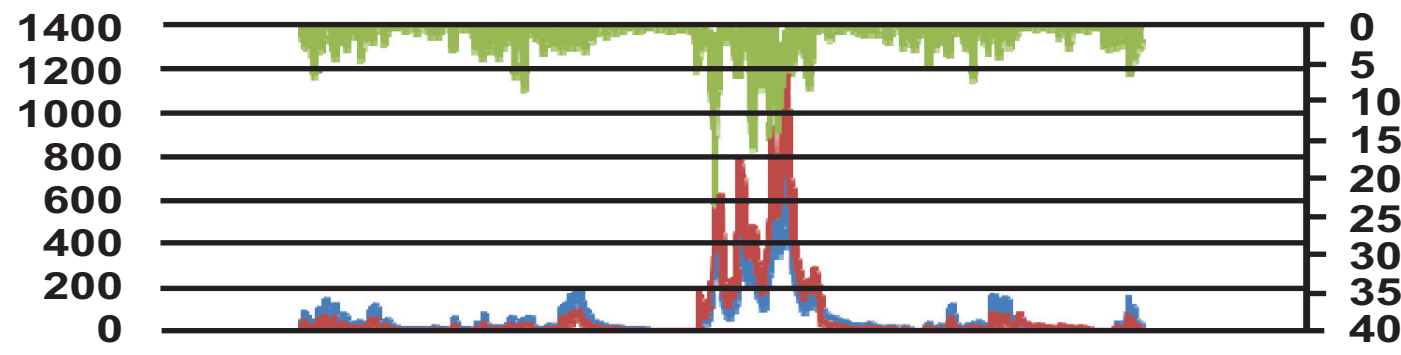

28/08/197602/10/197706/11/197811/12/197914/01/198118/02/1982

Time (Days)

Fig. (8). Calibration Results at the subbasin outlet 1G2 for the land use map of the year 1995.

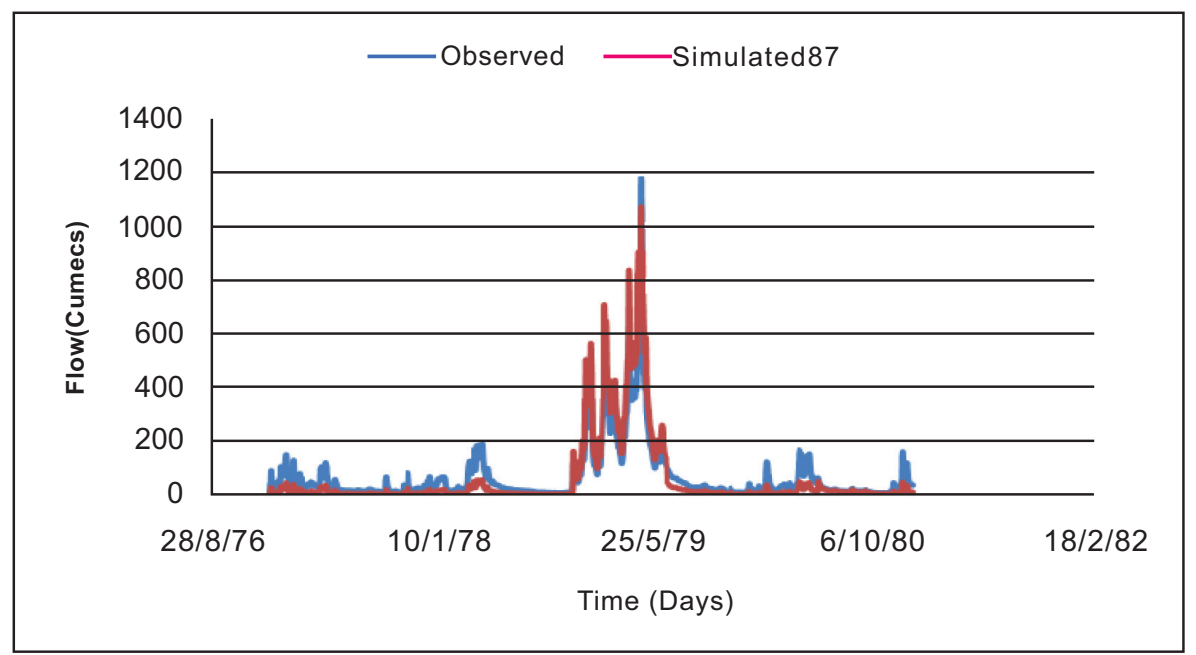

Fig. (9). Scenario 2: Simulated Hydrograph (land use map 1987)

forest decrease in the basin include the increase in farmland in order to ensure food security and hence clearing of trees for farm preparation, expanding settlements to meet population growth and other activities including cutting the forest for timber, construction materials and charcoal. In some areas of Wami, wetlands have changed into agricultural areas for rice and maize.

\subsection{Model Calibration}

The model was first calibrated for water balance and stream flow for average annual condition. Long-term simulation period from 1974 to 1981 was chosen to simulate the water balance for $1 \mathrm{G} 2$ which is considered the catchment outlet. The calibration results for the water balance for both surface and base flow components are shown in Table 5. Calibration and verification was performed for the periods from 1977 to 1980 and 1975 to 1976, respectively. Nash and Sutcliff efficiency criteria (NS), and the Index of Volumetric
Fit (IVF) functions were used to test the model performance. The Nash and Sutcliff coefficient after calibration was $52.2 \%$ and Index of Volumetric Fit (IVF) was 99\%.

The Simulated hydrograph (Fig. 8) shows the trend between observed and simulated flow during calibration, it can be observed that low flows are well reproduced in most periods.

\subsection{Land Use/Cover Change Impact on Streamflows}

The results from SWAT model simulation showed that the average river flows has decreased from $166.3 \mathrm{~mm}$ in 1987 to $165.3 \mathrm{~mm}$ in 2000 . The surface runoff has increased from $59.4 \mathrm{~mm}(35.7 \%)$ in 1987 to $65.9 \mathrm{~mm}(39.9 \%)$ in 2000 and the base flow decreased from $106.8 \mathrm{~mm}(64.3 \%)$ to $99.4 \mathrm{~mm}(60.1 \%)$ in 1987 and 2000 respectively.

From the simulated hydrographs (Figs. $9 \& \mathbf{1 0}$ ) it can be observed that the change in land use between the years 1987 and 2000 caused an increase in the peak flow because of the land cover change mainly from forest to agriculture and ur- 


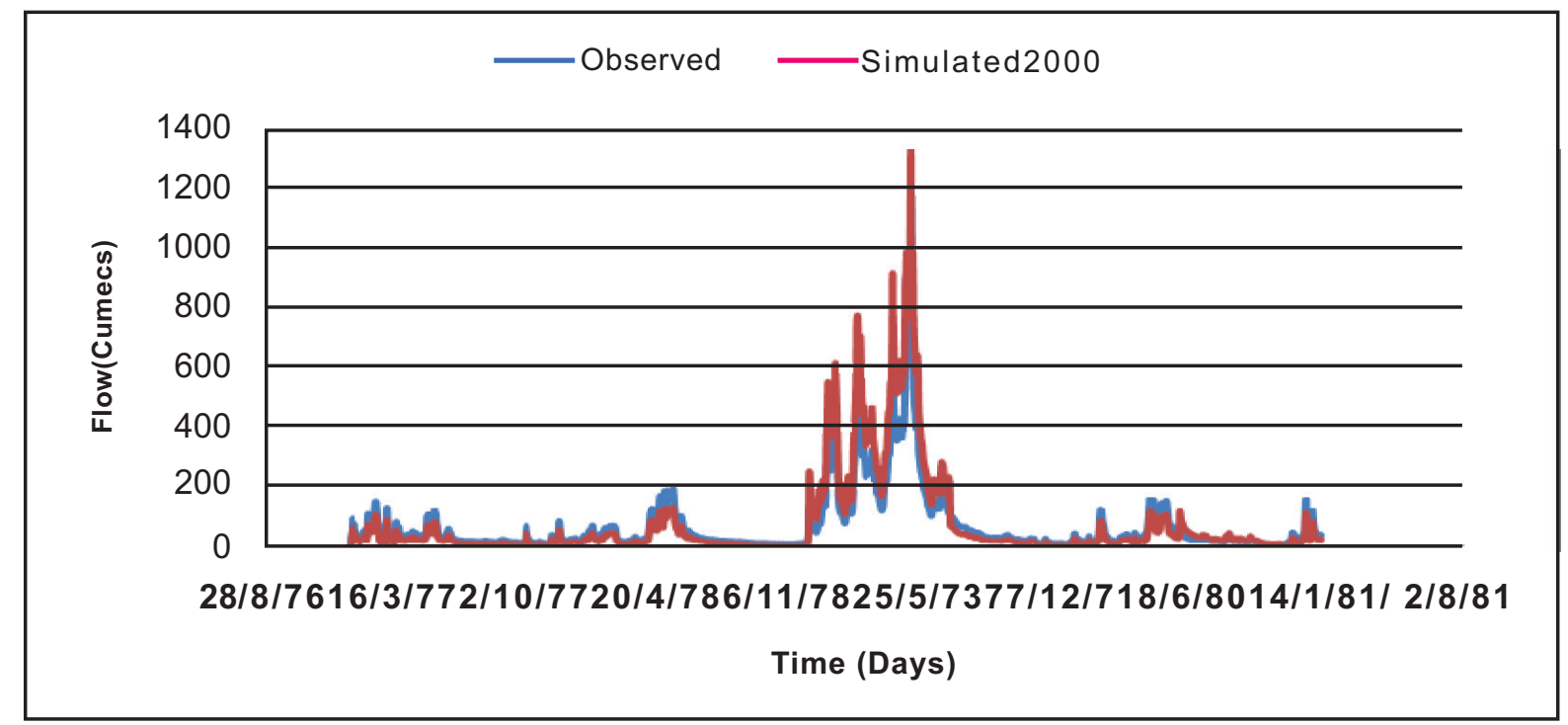

Fig. (10). Scenario 3: Simulated Hydrograph (land use map 2000).

ban areas. Analyzing peak flows for the simulated hydrograph, on $24^{\text {th }}$ of April 1979, the peak flows were 1069.5 $\mathrm{m}^{3} / \mathrm{s}, 1193.8 \mathrm{~m}^{3} / \mathrm{s}$ and $1324.6 \mathrm{~m}^{3} / \mathrm{s}$ for the land use data of 1987, 1995 and 2000, respectively. This trend shows that there is an increase in magnitude of surface flow which is directly associated with the change in land use cover type. The change in landuse has affected the ability of the soil to retain more water (infiltration capacity) during the rain prior to direct runoff.

\section{CONCLUSIONS}

A SWAT hydrological model was developed for analysing effects of land use/land cover changes on the stream flows. The model gave satisfactory results in terms of simulating observed flows. The study findings has revealed that the Land cover in Wami basin has changed significantly as a result of disturbances due to encroachment from farmers, fuel-wood collection and fires spreading from lowland areas. Degradation of the catchment has affected the flow characteristics in the basin as observed from increase in surface runoff and decreasing baseflow.

The main disadvantage of the SWAT model is the fact that it models many processes and hence $\mathrm{h}$

as hundreds of parameters and requires many data that make the calibration process tedious. In order to improve the performance of the model, it is recommended that more efforts should be put in place in collecting more rainfall data or rehabilitating the gauging stations which are not functioning at the moment so as to have good spatial representation of the rainfall data in the catchment. It is also recommended to use validated remote sensed data to complement ground measured data so as to have good spatial representation and to perform hydrological analysis of longer durations than the available ground measured data.

\section{CONFLICT OF INTEREST}

The author confirms that this article content has no conflicts of interest.

\section{ACKNOWLEDGEMENT}

Applied Training Project (ATP) Nile Basin Initiative

\section{REFERENCES}

[1] Costanza R, d'Age R, Groot R, et al. The value of the world's ecosystem services and national capital. Nature 1997; 387: 253-60.

[2] Meyer JL, Michael J, Paul W, Keith WT. Stream Ecosystem Function in Urbanizing Landscapes. J North Am Benthol Soc 2005; 24 (3): $602-12$.

[3] Doggart N, Loserian D. Eds. South Nguru Mountains: a description of the biophysical landscape. TFCG Technical Paper No 11. DSM Tz pp 2007; pp. 1-71.

[4] Im S, Hyeonjun K, Chulgyum K, Cheolhee J. Assessing the Impacts of land use changes on watershed hydrology using MIKE SHE. Environ Geol 2009; 57: 231-9.

[5] Schwarz GE, Hoos AB, Alexander RB, Smith RA. The SPARROW surface water-quality model: theory, application and user documentation. Reston, Virginia: U.S. Geol Surve 2006; Available from: http://pubs.usgs.gov/tm/2006/tm6b3/

[6] Neitsch SL, Arnold JG, Kiniry JR, Williams JR. a. Soil and water assessment tool theoretical documentation, Version 2005. Blackland Research Center, USDA Agricultural Research Service. Temple, Texas 76502 .

[7] U.S. Environmental Protection Agency (U.S. EPA). 1997. Center for Exposure Assessment Modeling. The Hydrologic Simulation Program - FORTRAN (HSPF): Available from: http:/www.epa.gov/ceampubl/swater/hspf/.

[8] Wami/Ruvu Basin Water Office (WRBWO). Business Plan. Wami/Ruvu Basin Water Office, Morogoro 2008a.

[9] Wami/Ruvu Basin Water Office (WRBWO). b. A Rapid Ecological Assessment of the Wami River Estuary, Tanzania. Prepared by Anderson EP, McNally C. Global Water for Sustainability Program, Florida International University 2007.

[10] Wami/Ruvu Basin Water Office (WRBWO). a. Environmental Flow Assessment (EFA), Wami River Sub-Basin, Tanzania: Socioeconomic component of the Wami River EFA Study. Literature Review for BBM Workshop. 2007. Wami/Ruvu Basin Water Office, Morogoro 2007.

[11] Wami/Ruvu Basin Water Office (WRBWO). d. Environmental Flow Assessment (EFA), Wami River Sub-Basin, Tanzania: The Wami Hydrology. Volume 1 - General Description. Wami/Ruvu Basin Water Office, Morogoro 2007.

[12] Arnold JG, Fohrer N. SWAT 2000: Current Capabilities and Research Opportunities in Applied Watershed Modeling. Hydrol Process 2005; 19: 563-72. 
[13] Arnold JG, Srinivasan R, Muttioh RS, Williams JR. Large area hydrologic modeling and assessment part i: model development. J Am Water Resour Assoc 1998; 34 (1): 73-89.

[14] Neitsch S, Arnold AG, Kiniry J, Srinivasan J, Williams J. Soil and Water Assessment Tool Manual: Version 2000. TR-192. College Station, Texas: Texas Water Resources Institute 2002.
[15] USDA-SCS. Hydrology. In national engineering handbook. Washington, DC: USDA-SCS 1972.

[16] Nash JE, Sutcliffe JV. River flow forecasting through conceptual models. Part 1.a discussion of principles. J Hydrol 1970; 10: 28290 .

Received: March 26, 2012

Revised: July 03, 2012

Accepted: July 20, 2012

(C) Nobert and Jeremiah; Licensee Bentham Open.

This is an open access article licensed under the terms of the Creative Commons Attribution Non-Commercial License (http://creativecommons.org/licenses/by-nc/3.0/) which permits unrestricted, non-commercial use, distribution and reproduction in any medium, provided the work is properly cited. 